\title{
Contesting Consensus. Disputing Inequality: Agonistic Subjectivities in Rural Bihar
}

Indrajit Roy

\section{OpenEdition \\ Journals}

Electronic version

URL: http://journals.openedition.org/samaj/3569

DOI: $10.4000 /$ samaj.3569

ISSN: 1960-6060

\section{Publisher}

Association pour la recherche sur l'Asie du Sud (ARAS)

\section{Electronic reference}

Indrajit Roy, « Contesting Consensus. Disputing Inequality: Agonistic Subjectivities in Rural Bihar », South Asia Multidisciplinary Academic Journal [Online], Free-Standing Articles, Online since 01 August 2013, connection on 01 May 2019. URL : http://journals.openedition.org/samaj/3569; DOI : 10.4000/ samaj.3569

This text was automatically generated on 1 May 2019.

\section{cc)}

This work is licensed under a Creative Commons Attribution-NonCommercial-NoDerivatives 4.0 International License. 


\title{
Contesting Consensus. Disputing Inequality: Agonistic Subjectivities in Rural Bihar
}

\author{
Indrajit Roy
}

\section{Introduction}

1 Within minutes of my meeting 35-year-old Gunvati Yadav outside her hut in the locality I will call Sargana Ward 1 during the winter of 2009, I was struck by her steely resolve against her neighbour, 50-year-old Ram Singh, whose mansion was the largest in the neighbourhood. She said she could not stand the sight of either him or his wife because of a long-standing dispute with them. When I ventured to ask what kind of dispute they were embroiled in, her husband reported it was over a piece of property. Gunvati was quick to contradict him-forcefully: 'Don't listen to him. It's all about barabari (equality).'

2 The literature on the politics of the 'poor' has pointed to the manner in which the disputes they are embroiled in are about access to and control over resources, or defending what little they have from encroachments and infringements by the rich and the powerful. Other strands in the literature have drawn attention to their incorporation into 'identity' politics, mediated through categories of caste, religion and community. While the analytic salience of these approaches may be justifiably questioned, I contend that they are also motivated by a desire to assert their social equality and accomplish their political imaginaries.

3 To attain their objectives, the 'poor' supposedly draw on their cultural resources-such as the language of fictive kinship, the moral claims on socially 'superior' individuals or pleading with powerful patrons-to advance their claims or defend their interests. Specific variants of this argument stress that their interaction with the state tends to be fragmentary and, as a result, they seek evasion from the law-either through autonomy or exemption. While it is not entirely untrue that cultural resources are sometimes 
deployed, or that access to the state is often fragmented, I suggest that these do not deter the 'poor' from seeking greater, not lesser, access to the state and its de jure versions.

In this paper, I intend to shed some light on what Gunvati Yadav's struggle with her neighbour might tell us about the manner in which the rural poor in one of India's most impoverished regions engage with and in politics. I will do this by analysing the way in which Gunvati and her husband Narendra tried to forestall the perpetuation of, and eventually contribute to the rupture of, elite-based consensus in their neighbourhood. I focus on their dispute with their wealthier Rajput neighbour Ram Singh, a dispute that occupied the collective imaginary of the inhabitants of Sargana Gram Panchayat ${ }^{2}$ in north-east Bihar, India, for nearly five years, from 2005 to 2010. This dispute will be located against the backdrop of the fundamental social churning that the State has seen over the last two decades.

5 At the heart of this churning has been the question of ijjat (dignity) and samajik nyay (social justice) for those historically subordinated and oppressed by the region's elites. These relations of subordination and oppression were buttressed by the caste hierarchy. The custodians of this hierarchy, the self-styled 'upper castes', were for long affiliated with the Congress Party, the political organisation widely credited with securing India's independence from British rule. The Congress Party controlled India's national parliament uninterruptedly for the first thirty years after the country's Independence. By 1967, the party's stranglehold was breached in Bihar and several other States by an increasingly assertive coalition of cultivator castes, whose ritual status is perhaps best described as 'intermediate'-'lower' than the self-styled ritually 'pure' 'upper' castes, but 'higher' than those stigmatised as 'untouchables' (Frankel \& Rao 1989). The Indian state categorises these 'intermediate' caste groups as Other Backward Class (OBC): in the State of Bihar, the assertions of the OBCs were led primarily by a coalition of Yadav, Kurmi and Koeri communities. Among these, the Yadavs are numerically by far the most preponderant, estimated at $15 \%$ of the State's total population (calculations in Robin, 2011).

6 In 1989, coinciding with what Yogendra Yadav has termed the electoral participatory upsurge, the Janata Dal formed the government in the State. As Cyril Robin (2009) reminds us, the caste profile of the State's legislatures underwent a major transformation, and began to more (but by no means completely) genuinely represent the population of the State as a whole. The Yadav leadership of this social coalition was unmistakable, given the charisma and leadership of the charismatic Lalu Prasad Yadav, the man who became Chief Minister for the ensuing fifteen years (de jure from 1990 to 1997, and de facto from 1997 to 2005). In 2005, the Yadav-led government was routed in the polls, to eventually give way to one led by the astute Nitish Kumar, of the Kurmi community. Kumar's government represented a multi-caste coalition, comprising members from the 'upper castes', non-Yadav OBCs as well as segments of the State's Dalit and Muslim populations. Progressive critics have worried that this coalition signifies the restoration of the caste power of the 'upper' castes. This anxiety has a very real basis, given that the Hindu Rightist Bharatiya Janata Party was till very recently Kumar's coalition partner. ${ }^{3}$ However, the gains to the agenda of social justice in Bihar are more irrefutable than what critics would account for. In particular, as we shall see, the reclamation of social equality in the imaginaries of the rural poor is an important political achievement that deserves to be analysed in its own right. 
7 This paper explores the 'agonistics' of the dispute between the two neighbours in order to illuminate the emerging socialities in rural Bihar. These socialities are underpinned by the interrogation of assumed privilege and authority, and the affirmation of equality by the rural poor. The paper draws on Chantal Mouffe's insights pertaining to 'agonistic democracy' to examine the assertions advanced by the landless Yadav couple against the 'deliberative' solutions that Ram Singh and his wealthy allies sought to impose on them. The arguments presented in this paper resonate with Jacques Rancière's suggestion that 'egalitarian effects occur only during a forcing, that is, the instituting of a quarrel that challenges the incorporated, perceptible evidence of an inegalitarian logic' (Rancière 2004: 5). Rejecting the deliberative 'solution' offered by the neighbourhood elite, the Yadav couple takes recourse to the legal arm of the state. In doing so, they seek its extension, rather than exemption from it. They actively seek to be incorporated into the 'grid' (Jansen 2013) of the state, be governed by it and have their belligerent neighbours governed by it as well.

8 The paper proceeds along the following sections. In Section 2, it explains the research methodology. In Section 3, it outlines the key themes emerging from an analysis of the dispute under study. This is followed in Section 4 by a discussion of what this implies for the manner in which claims of equality were forced upon social superiors. Section 5 concludes.

\section{Methodology}

9 In analysing this dispute, I follow Comaroff and Roberts' insight that the 'dispute process may provide an essential key to the disclosure of the socio-cultural order at large' (1981: 249). In this sense, I agree with Caplan's (1995) suggestion to view disputes as not only about material goods and the right to make decisions, but also about configuring social relations. The contextualisation of disputes is important as they can be analysed as reflecting contested meanings and conflicting interpretations. This insight informs the argument in this paper. In charting the way the dispute is sought to be resolved, the analysis considers what Marc Galanter (1963) has called 'local law-ways', meaning those norms sanctioned by individuals and groups whose authority is based on their position within restricted political systems, and in which the presence of nation-state authority is not essential. Early observers of Indian villages, such as Louis Dumont (1970), David Pocock (1973) and Daniel Thorner (1962) saw dominance and exploitation as key to the social structure: disputes were epiphenomena of structural or cultural inequalities. Later observers, such as Beals and Siegel (1966), began to emphasise the pervasiveness of factions, and disputes began to be analysed in terms of the opportunities they provided to factional leaders to underscore their importance. However, as Bernard Cohn (1965: 97) reminds us,

Dispute settling, norm setting, and norm enforcing are situational and every dispute or breach of norms involves a kind of social algebra on the part of the actors in the situation to see what lines of cleavage will be affected by what alliances they make.

10 For this paper, I rely on the qualitative analysis of ethnographic data. This is motivated by the nature of the data, which comprises notes from observing interpersonal and social interactions and the recollections among respondents of past and contemporary events. In reconstructing the events of the past, I draw on interviews with neighbours and 
friends of the two disputants, relying on their memory. The rhetoric of their claims is of interest, even as it is impossible for me to verify this accuracy. Where claims made by one or the other party were disputed by others, I have reported so in my account. I elicited as many different shades of opinions as I could, using the rapport I had developed with the different individuals to ask provocative questions. However, I make no claims, contrary to the advice of the founders of the 'participant-observation' method (Malinowski, 1967), to rescue objective knowledge from the screen of subjective experience. In this, I follow Rabinow (1977) and Clifford (1986) who elaborate and incorporate the blurred distinction between the objective and the subjective dimensions of ethnographic work.

11 I have tried to ensure that a reflexive approach to data collection informs my analysis. Not only was my positionality as clearly conveyed as possible, but I actively sought out the 'contestations and competitions of socially lodged and leveraged discourses' (Marcus \& Fisher, 1999: Xxx). Indeed, I recognise that at any given time, what I had access to was the partial truth. I find that the distinction between true and false, as between hearsay and historic fact, is neither necessary nor useful. Indeed, '(i)f we treat all versions of false stories as if they were true, we get a glimpse into the world our informants described to us' (White 2001: 295). The analysis is interpretive, not only because it involves an interpretation of what my respondents narrated to me, but also in recognition of the fact that their reports were themselves an interpretation of reality.

I should also clarify my positionality. I lived in Gunvati and Narendra's home for most of my entire stay in the village. I 'hung out' with them and deployed the technique of what in a sanitised world would be called 'participant observation'. I took care to maintain the distinction between 'participant-observation' and 'observer participation', except at the very end of my stay when I accompanied the couple's well-wishers to make claims on their behalf. Despite making evident to my hosts my sympathies with them, with that one exception, I steadfastly remained an 'observer', sometimes to their irritation. Admittedly, I unmasked the façade of neutrality in my notes, due to which my account might appear at times to be biased in favor of Gunvati and Narendra Yadav.

\section{Contours of a dispute}

13 Disputes such as the one under discussion are often joined in by others in a locality, not always in self-interest, but also to demonstrate solidarity, show off one's importance and express personal concern. They speak to a range of affective commitments in the neighbourhood and beyond. On the face of it, the property involved in this particular dispute was merely a tiny fraction of some of the other major land disputes in the locality. But it meant considerably more to the contending parties, as we shall see. The dispute had apparently been the talking point of the locality for many years, including at the bazaar, in social functions and among local politicians: it certainly was during the five months that I lived there.

\section{Neighbours, friends and foes}

14 A very cursory introduction to the Yadav couple is in order. Narendra Yadav's origins are extremely humble. According to both well-wishers and antagonists, his father was a sharecropper, attached to a Yadav farmer with many hectares of land in Ward 5. He had moved to this village from Darbhanga after his wife, Narendra's mother, had been 
condemned as a witch by the 'upper caste' Rajput landlords of their native village and burnt to death. After his father's death, Narendra asked to be freed from the sharecropping arrangements with the farmer. As his father had cleared all his dues, this was readily acceptable to the farmer's family. Of course, this meant Narendra had no secure source of income. To support the family, in 2002, he began working in Punjab (over 1000 kilometers to the north-west), first as an agricultural laborer and then as a mason. By all accounts, the family's economic and social position began to improve since he started working in Punjab. Gunvati married Narendra in 1992. She had been orphaned as a child, and had been raised by her grandmother in a neighbouring village. After her grandmother's death, she was adopted by a cousin of Saroj Srivastava, who arranged her match with Narendra.

With increased earnings and savings, the couple purchased a modest plot of land measuring nine dismil (less than one-tenth of a hectare) in 1997. Well-wishers recall that when they did so, their new neighbours were taken aback. Most of the families in that neighbourhood are either Rajput or Kayasth, both 'upper caste' communities. Each of these properties is at least 40 dismils in area, reflecting their relative prosperity vis-à-vis Narendra. Their neighbour to the east is the college-educated Ram Singh, an agriculturist who owns nearly eight hectares of cultivable land. He also owns two tractors, one of which he rents to other farmers. He and his wife have two children. Their son works with an IT firm in Delhi, while their unmarried daughter lives with them. Ram Singh is one of the executive members of the Village Education Committee. He is personally known and well-regarded by most of the politicians in the locality. He is a regular invitee to the poetry-reading sessions organised by the foremost literary figure in the vicinity. His father-in-law Harish Singh is extremely well-connected with upper echelons of the bureaucracy.

The Yadav couple share their western boundary with Pradeep Srivastav, retailer of the local fair price shop where fuel and food are sold to the poor at subsidised rates. To the north of their plot lies a clump of bamboo woods, recently purchased by Dharmesh Srivastav, who also owns a shop in the bazaar with one of the three photocopiers in the vicinity. Dharmesh is the younger brother of the local chief of the Bharatiya Janata Party (BJP). An unpaved road abuts the Yadavs' plot on the south. Across the road lives Pintu Srivastav, who works with the Central Government's Polio Immunisation Program. His family is very intimate with Ram Singh's.

The unpaved road connects Sargana with the main business town of Raiganj three kilometers away. The Yadavs purchased the plot at a throwaway price of less than 15,000 rupees. It is, however, expected that its value will increase exponentially once the road is paved. Given the feverish pitch at which the Nitish Kumar government has been constructing roads across the State, this is widely anticipated within a few years. ${ }^{4}$ Already during the period of my fieldwork (2009-10), the plot was estimated to value 100,000 rupees. The financial possibilities offered by an investment in any property on this stretch have added tremendously to its monetary value.

The Yadavs are not the only non-'upper' caste property-owners in this neighbourhood. A few other houses are owned by members of other caste groups. Two belong to schoolteachers employed in the High School nearby: they are both Dhobhi, ritually stigmatised as 'untouchable', but who have nevertheless battled the odds against them aided in part by the Indian state's affirmative action policies. Another house has recently been purchased by a Bhagat family whose patriarch was a contractor: Bhagats are 
classified by Bihar's administration as Extremely Backward Class (EBC), a subset of the $\mathrm{OBCs}$ and occupying a lower ritual position than the Yadavs, Kurmis and Koeris in the caste hierarchy. All these houses, including the one the Bahagats were constructing at the time of my fieldwork, were concrete structures at least storeys floors high. By contrast, the Yadavs' house was single storeyed, and looked the plainest in the neighbourhood. Gunvati Yadav recalls being called maatbars (upstarts), and addressed as 'people who had nothing to cover their bottom with, but aspiring to wear a turban on their heads'. ${ }^{5}$ Ram Singh and Pintu Yadav did not, it seems, conceal their dislike of having to share their neighbourhood with someone who was so obviously unlike them. She told me, 'They have always wanted us to go away and live in the Yadav quarters, the more congested part of the village. Why should we? Just because we are poor?' The Bhagats were much more intimate: their twelve-year old boy regularly bathed in their house and ran errands for them. They were on speaking terms with the Dhobhi family, but not particularly friendly. Their relations with most of the Kayasth neighbours were cool, not particularly effusive, but not hostile either. Electorally, most of the households here supported Nitish Kumar's dispensation: either its BJP constituent or Kumar's own JD(U). Narendra and Gunvati did not, and remained staunchly committed to Lalu Yadav and his party.

The couple was very close to the family of the farmer with whom Narendra's father had been 'attached' as a sharecropper. Narendra was particularly friendly with the farmer's son Amaresh, and considered him his well-wisher. Gunvati was less sure about Amaresh's reliability because of his penchant for alcohol. She was also wary of his political ambitions- he had been elected to an important post in the Gram Panchayat and was a political activist affiliated with Lalu Yadav's party-as that made him 'inherently' opportunistic, she alleged.

The dispute between the Singhs and the Yadavs originated in the latter's allegation that Ram Singh's family had encroached into and claimed nearly a tenth of their property. Ram Singh countered this charge accusing Narendra Yadav of illegally constructing on his territory. Indeed, a review of the documents showed that Narendra did not possess the legal evidence to claim that the entire plot was his. The copy of the "partition suite' available with him was a provisional one (kachhi pratilipi), unlike the formal copy (pakki pratilipi) of the same document which Ram Singh was able to produce as evidence. This 'evidence' was held suspect generally, as it was believed in the locality by several people (not all of whom were friends to the Yadav couple) that Ram Singh had forged these documents using his clout with the influential men of the locality.

Interviews with different neighbours and with the Yadav couple suggest that the dispute began sometime in 2004/5. Taking advantage of Narendra's absence to Punjab, Ram Singh surreptitiously shifted the bamboo fence on the boundary between the two plots by a few feet into Narendra's plot. Their neighbour Malini Srivastav recalled how Gunvati raised a furor over Ram Singh's actions. Ram Singh and his family retaliated by heaping abuse on her. His wife and daughter commented on Narendra's mother and how 'she deserved the fate she met." Gunvati's riposte to Ram Singh's wife was as acerbic as it was swift: 'Don't talk like that about a dead woman. What about your character? Your daughter does not even look like she is her father's child. She looks more like your father's child.'

Four years on, she recalled how she realised after she had made those utterances the full import of what she had said. 'I wasn't thinking, I was just extremely angry,' she told me, rage flashing across her face as she did. Her comment appeared to trigger a caste war. 
Stunned by her diatribe, Ram Singh gathered his co-castemen together and barged into their plot. Gunvati recalled:

They did not dare to touch me or anything else in their house. Lalu Yadav was still in power. They knew that it they did anything to me, they would not be spared. My son ran to the Yadav tola to inform the people there, and Amaresh in Ward 5... Within an hour, all the Yadavs in the neighbourhood turned up in their own and hired vans and bikes. Others came on foot, some on cycles. The Rajputs were very scared. I hadn't realised I could assert myself so strongly... ${ }^{8}$

Given the long history of caste conflict in the State, especially memories of the RajputYadav conflicts that have been characteristic of the State's political-economic landscape (Jannuzi, 1974; Rao \& Frankel, 1989), this impromptu mobilisation bringing together highly combustible elements could easily morph into a civil conflict. However, much to everyone's relief, what followed was only a verbal duel-one in which both parties hurled the 'filthiest expletives' at one another. Sneha Bhagat, another neighbour, remembers,

It was very frightening. Anything could have happened. Both sides were screaming. But it was nice to see the look on the Rajput faces. They were terrified. Gunvati stood transformed-from the demure bride of a few years ago to the goddess Chandi herself. ${ }^{9}$

However, timely intervention from some of the local elected representatives saved the village from a general conflict. The parties dispersed. Everyone was relieved that there was not going to be a riot. The status quo remained.

In his review of the proximate hostilities that mark social relationships in the Greek nation-state, Herzfeld suggests that 'the very set of concepts that appear to pit Greek against Greek is at the same time the affective disposition that binds them together' (Herzfield, 1995: 133). We learn from Chantal Mouffe's incisive reading of Carl Schmitt about 'agonism' as the contested space between friendship and enmity, between deliberation and antagonism, and between cooperation and annihilation (Mouffe 1992, 1996, 2007). As the affective dimension of politics becomes more and more salient (Goodwin, Jasper and Polletta, 2001), it becomes imperative for scholars to take seriously the 'agonistics' of disputes, how they arise, are presented and sought to be resolved. We need to note how, on the one hand Gunvati responded to her neighbour's taunts and provoked them further, and called on her sympathisers and supporters-mostly, but not exclusively from her own Yadav community-to defend her. In her first confrontation with them, she pays scant heed to concerns about her own safety, and gives vent to her anger and frustration at being 'talked down to'. She challenges a male from a caste 'superior' to hers on the caste hierarchy. Moreover, she and her neighbours report being happy to see the Rajputs threatened. On the other hand, she is also relieved not to have a full-blown caste conflict on her hands. This tussle, evident from taunts, expletives and abuses-to be followed by relief at not having a physical conflict-, emblemises the 'agonistic' dimension of the dispute.

Following Herzfield, Singh has recently elaborated the intermeshed modes of cultural relations in his fieldwork locality in central India as marked by what he calls 'agonistic intimacy': relations that were neither exclusively hostile nor affirmative of shared communitarian values (Singh, 2011). This notion is a potentially valuable addition to the repertoire of authors seeking to analyse the dialectics of political relations in a rapidly transforming social milieu such as rural Bihar: Singh applies it to explain the proximate hostilities between the Sahariya community and their neighbours in rural Central India against the persistent but strained caste hierarchies, "not overwritten either with a 
wholly negative valence of hostile contradictions..., or with entirely affirmative hopes of trust, community...' (Singh, 2011: 431). While I remain unconvinced that the 'heartwarming' connotations of the term 'intimacy' appropriately illuminate the mutual bitterness that characterises the relations between the disputants, the conceptual space occupied by these relations certainly map onto an 'agonistic' compass.

Gunvati's refusal to allow Ram Singh's intrusions to proceed unchallenged is an important reminder of the manner in which the question of equality, dignity and social justice continue to permeate the quotidian lives of the rural poor, even as these are being constantly flouted by local elites. The challenge that Gunvati throws serves to point the constructive- almost generative- role of passion in day-to-day political transactions, particularly those that aim to rupture prevailing assumptions of authority. Fifteen years of supposed Yadav raj notwithstanding, Ram Singh and his Rajput co-caste men assumed that they could violate Gunvati's property, enter it with impunity and threaten her body. But she would have none of it. She, on the other hand, is content with a show of strength, with the Yadavs turning up as a threat to the Rajputs: thereafter, she is actually relieved that there would be no violence. She recognises that without her provocation, the situation would not have reached the stage it did. She is glad that she catalyzed the provocation and the subsequent face-off. But she is also pleased that the face-off did not escalate.

\section{Deliberative attempts...}

Availing of an agonistic compass to conceptually navigate the relationships between the two contestants and their friends also enables us to think about the way in which the dispute is deliberated upon in the locality. Narendra returned within a few days after being informed over telephone of Ram Singh's intrusions. He sought the willingly forthcoming support of Amaresh Yadav, his old friend, and Dharmesh Srivastav, his neighbour to the north. Amaresh's and Dharmesh's was an enduring friendship despite several social and political differences between them (Amaresh was Yadav and Dharmesh Kayasth, the former an agriculturist and the latter a retailer, the one a committed supporter of Lalu Yadav and the other a votary of that leader's bête noir the BJP). Upon reviewing the documents available with Narendra, Dharmesh advised caution in dealing with Ram Singh, since 'the partition suit Narendra possessed was only provisional. ${ }^{10} \mathrm{He}$ suggested that, given their tenuous legal position, they ask a panchayati to be convened in order to resolve the matter. The panchayati refers to an informal deliberative institution convened for resolving disputes among villagers. Its ethos was commonly described as an attempt to consultatively (miljulkar), on the basis of sound arguments (yukti-purn charcha), strive towards a consensus (ekmat hona) or at least a compromise (samjhota). From his own experience, he recounted how complicated the legal machinery could be and therefore, how it was better to garner support from within the community, in order to pressure Ram Singh to revert to the status quo.

As a deliberative body, the panchayati was respected in the community, or so Dharmesh argued. Certain well-known norms were supposed to discipline its proceedings. The 'facts' of the case would be summarised by the person who asked for the panchayati to be convened (in this case Dharmesh). Then the person with the grievance (akin to the 'plaintiff' in the formal legal system) would be asked to specify his complaint (in this case, Narendra). Thereafter, the person against whom the grievance was being aired would be 
asked to defend himself (Ram Singh). Following this, the issue would be opened up for discussion and the members of the panchayati would be asked to make a judgment. Throughout the panchayati, neither party could speak or influence the proceedings, although of course they were expected to answer questions that emerged from the group. Five men-the panchayat-were tasked with the actual act of 'judging' the case: their verdict was expected to be based on and derived from the prevailing opinion in the panchayati, rather than autonomous of it. It was customary to solicit as many shades of opinion as was possible. The presence of these norms reflects a deliberative conception where decisions could be taken 'according to the exchange of reasons and arguments (broadly conceived and defined) that appeal to shared objectives... or values' (Fung 2005: 401).

Gunvati remained skeptical of this approach. Rehearsing their debate, she recounted to me, in Dharmesh's presence, 'I didn't like the idea of the panchayati, since my husband would have to cower before the influential people who would be present there.' Her Gunvati's apprehensions about the panchayati stemmed from the principle behind the organisation of the panchayati: that some 'wise men' (jaankar log) would sit on judgment over a case and hear out the arguments made by both sides. Assuming that they were all impartial and unhinged from the dynamics of power and politics, she asked, would that still be the correct (vajeb) way to resolve the dispute?

Do they not already know what the situation was, before he tried to grab our property? If they say they don't, how will the panchayati help? And if they do, why need a panchayati? Those who can argue well will prevail, not those who are right. Our property has been usurped. But if my husband can't open his mouth in the panchayati, they will say he has no argument and award the property to them.

For Gunvati Yadav, thus, the very principle of deliberation that supposedly underpinned the ideal of the panchayati system of dispensing justice appeared flawed. More so, when they would be expected to adhere to the decision even if its judgment would be patently unfair towards them. GunvatiHer worries resonate with some well-rehearsed criticisms of a deliberative conception of democracy. They take analysts beyond the usual inculpation of the imperfect manner in which deliberations are conducted and compel us to interrogate their very foundations. Constitutive of these foundations, political philosopher John Rawls tells us, is providing public justification for claims (Rawls, 1997: 786). In the accounts of deliberative democracy inspired by him, the onus lies on the contending parties to prove the strength of their case. Furthermore, once decisions have been deliberatively taken and agreed upon, the onus lies on those dissenting to justify why their position should even be considered for discussion. But, as Stanley Cavell, asks in response to Rawls' enunciation of political liberalism, 'what if there is a cry of justice that expresses a sense not of having lost out in an unequal yet fair struggle, but of having from the start been left out' (Cavell, 1988: xxxviii). This sense of closure that the panchayati would seek to impose its participants worried Gunvati no end. She was further perturbed in the knowledge that the deliberators were all men from the ritually 'superior' castes and relatively wealthy. There were a minority who were not, and they were the only anchor of hope for cynics such as her. The deliberators were embedded in the politics of the locality and fully aware of the Yadav couple's material and social position. Many of these deliberators had in the past scoffed at their 'pretensions' and aspirations to live in a neighbourhood with wealthy families. Although not all of them were enamored of Ram Singh, they were socially proximate to him, adding to Gunvati's claims that they could not be trusted to be impartial. 

posed by 'background inequalities' (Cohen, 1997: 75) are in fact challenges stemming from imperfect implementation rather than the model itself. Of course, Gunvati's tussle with her husband and their friends over the question of approaching the panchayati has therefore to be understood against the persistence and reproduction of social inequality in rural Bihar. This persistence and reproduction is not merely a matter of objective truth (in terms of 'gini coefficients', income and wealth concentrations), but is also felt and experienced (through taunts, humiliations and visible disparities in assets). The existence of material disparities are recognised by Gunvati, her husband and their well-wishers. That these could and would bolster the specific discursive practices of decision-making in the panchayati are not lost on her. the deliberative model. She finds it justifiably difficult to distinguish the procedural from the substantive aspects of the panchayati. Indeed, recalling Cavell's criticism of Rawls, Chantal Mouffe (1999) calls into question the conceptual distinction that is sought to be drawn between the procedural and substantive aspects of deliberation. She argues that the two aspects cannot be separated out, even conceptually, because 'procedures' are necessarily 'substantive' in that they are based on certain shared conceptions and imagination of the 'good life'. The premise that only 'wise' and 'wealthy' men should deliberate is not a procedural flaw (indeed, it is emphatically not), but reflects substantive moral commitments. Consequently, they represent societal prejudices and the repression of what is considered deviant, thereby universalising particularistic norms and values.

Furthermore, Mouffe calls for an explicit recognition of the role of power in the structuring of deliberations. The exercise of power relations and relations of domination and subordination cannot be wished away. It is a fact of life, and should therefore logically inform political theory and philosophy. That several of the deliberators were from the 'upper castes' was a dreadful prospect for Gunvati. That there were many from her 'own' Yadav caste did not offer any consolation to her either. 'This village is full of gaddars (traitors)', ${ }^{11}$ she told me, her voice hushed, but clear. 'People can't tolerate others doing well, especially not poor people. They want us to remain poor.' Gunvati's agonies vis-à-vis the panchayati thus stem from a dual discomfort: the presence of power relations skewed against her and her husband on the one hand, and the assumption that the reasoned deliberation of a committee of self-styled 'wise' men-even if they were of great personal integrity-should be invoked to arrive at consensus.

\section{...and failures: the reconstitution of authority}

Despite Gunvati's objections, Dharmesh asked for a panchayati to be convened. He told me later that he had hoped that by appealing to a sense of being 'nyaysangat' (just), he could make Ram Singh back down from his position. In this, however, he was eventually unsuccessful. At the panchayati, held in the early winter of 2006, the prevailing view emerged that Narendra (not Ram Singh) should seek peace. The panchayat comprised two Rajput men, two Kayasth men and one Yadav, the traditional chief of the community. Their deliberations were duly consultative. Ram Singh's Rajput clansmen overcame their factional rivalries for a while to 'persuade' the panchayati to ask Narendra to 'compromise' (samjhota). They were supported by members of the old-established Kayasth 
elite, who viewed Dharmesh as an outsider and an upstart. The wealthy Yadavs of the locality also supported Ram Singh's position, and vociferously defended, according to Narendra, the status quo: it appears they feared that supporting Narendra on this occasion would make it unfeasible for them to defend the encroachments they had committed upon the land of their neighbours. The two Dhobhi households of the neighbourhood also supported this position. Narendra's well-wishers included Dharmesh and Amaresh, as well as the less wealthy members of the Yadav and Kurmi communities. In addition, members of the Kevat, Dusadh, Muslim and Musahar communities stood by him.

The panchayati was categorical in its support to Ram Singh's cause. This appeared to have dealt a death-blow to Narendra's claims. For the panchayatis were regarded as 'ancient institutions', and many people in the village perceived their role as exceeding that of resolving disputes. As 'de facto sovereigns', to borrow from Hansen and Stepputat's formulation, they have possessed 'the ability to kill, punish and discipline with impunity.' (2006: 295). As the emerging literature on informal sovereignty suggests, effective legal sovereignty continues to be tenuous in societies where sovereign power has been historically contested by many other forms of local authority. Given the continued incapacities attending to state-formation in post-colonial contexts, it might be expected that the panchayati's decision would be adhered to and respected by all, including those who were disadvantaged by it.

It was not. Although Gunvati's worst fears had come true and the panchayati sought a compromise that would be against their interests, the couple and their well-wishers had other alternatives in mind. Amaresh Yadav was particularly keen that the couple file a case with the Gram Kachari, of which he had been elected upsarpanch (Deputy President) the previous year. The Gram Kachari was an elected village-level institution that had been formally tasked by the State Government with the responsibility of resolving village-level disputes involving resources of less than 10,000 rupees. Amaresh Yadav promised them that he would ensure that the Kachari resolve the matter in their favor at the earliest. He confided in me that his motivation was to show that the Kachari, which had been reinvigorated after a two-decade long period of dormancy, was playing a role in people's lives. Further, if he could facilitate a resolution of the dispute in Gunvati and Narendra's favor, he could improve his prospects as a political leader with a reputation for solving the problems of his constituency. The elected panchs (representatives) of the Gram Kachari unanimously passed a resolution endorsing Gunvati and Narendra's position, but this time it was Ram Singh who refused to abide by their ruling. The Gram Kachari, on its part, convened as it was barely a year prior, was not in a position to enforce its ruling. Consequently, the status quo was maintained. Gunvati continued to taunt Amaresh Yadav about his inability to convert his official position as upsarpanch into something more substantive: she did this at least twice in my presence in 2009/10. At least in my presence, Amaresh Yadav usually responded in a good-humored way, making light of her remarks and consistently assuring her that he was trying his best.

With the panchayati's decision perceived to have been inconsistent with the requirements of justice ('nyayasangat nahin tha' was Dharmesh's refrain)-and the Gram Kachari too nascent then to be of much help-they decided to approach the amin, an appointed (block-level) legal officer responsible for endorsing property-related matters. If he found the provisional documents Narendra possessed to be genuine, he would endorse them, and verify that the disputed piece of land indeed belonged to him and Ram Singh was the 
usurper. Gunvati and Narendra's willingness to contest the panchayati's decision reveals the conceptual contribution of an agonistic view of politics. Mouffe argues that theorists and philosophers must appreciate the constitutive role of conflict in interrogating the basis and exercise of power. Against 'reasoned' and 'rational' deliberation then, she contends that 'contestations' should be encouraged and made central to discursive practice because, as she suggests, 'for democracy to exist, no social agent should be able to claim any mastery of the foundation of society' (Mouffe 1996: 247). At the same time, Ram Singh's denunciation of the Gram Kachari revealed the resistance among elites to submit to even the notion of popular sovereignty. His reaction cautions analysts against romanticising the agonistic dimension of politics. As power leaches somewhat ineluctably towards members of marginalised groups, the prospects of 'elite revolts' (following Corbridge and Harriss, 2000) become more and more concrete.

Adopting an 'agonistic lens' makes it possible to theorise these contests over authority and meanings. In a scenario where the overt use of force and violence is subdued, the conceptual lens of 'agonism' allows us to appreciate the domain of social relations that lie between subservient cooperation and subversive conflict. Furthermore, it also conveys the interlocked nature of the tussle between the two contesting parties, with neither succumbing to the pressure of the other.

\section{Contentious conversations, unreasonable motifs}

The couple's decision to approach the legal institutions representing the de jure sovereignty of the state was fraught with a new series of uncertainties. Although the amin, of the Kevat ${ }^{12}$ community, was not known to be particularly caste-conscious in his dealings, he delayed measuring the land (and the consequent endorsement) for over thirty months, from March 2007 to December 2009. Over this period, he gave an appointment to Narendra and Gunvati eighteen times, but did not keep it even once. Narendra believed that Ram Singh's influential father-in-law had bribed him, but his fears were allayed by Amaresh Yadav, who kept- at least according to his own report-in constant touch. Two other subordinate amins had also been appointed, and they conveyed their satisfaction with the papers in the Yadav couple's possession to the chief amin. When the chief amin finally did arrive at the disputed plot in March 2010, he remained noncommittal and refused to endorse any position, adding to the couple's agony. After waiting nearly a month, Narendra, Dharmesh and Amaresh trooped down together to the amin's office to have a showdown with him. I accompanied them. The three men first approached the bureaucrat to whom the amin reported. The conversation ended with the usual banalities, with the bureaucrat assuring us that he would do his best to ensure that the matter be speedily resolved. On their way out, they happened to meet the amin, and began to address ${ }^{13}$ him thus.

Amaresh: What's going on? We demand to know. Why is a task which should not take more than ten minutes taking more than three years?

Another well-wisher of Narendra's (a passer-by): Narendra is a poor man. Why are you deliberately making life difficult for him? If he just hangs around here, waiting for you to take the measurements, he will starve.

Dharmesh: What exactly do you want? Why don't you name your price, if you want a bribe, and we'll pay it?

Amin (looked at Narendra threateningly): How dare you people talk to me like that? Am I not trying to help you? If you persist this way, I will not do anything. 
41 The amin appeared to be trying to play on Narendra's fears, hoping that he would ask Dharmesh and the others to back off. Narendra didn't. On the contrary, he retorted, 'I have nothing to lose anyway. If I kill you, they'll throw me in jail. At the most-I won't get to earn. In any case, I am unable to earn.' After a stunned silence, Dharmesh picked up the conversation,

Look, here is a poor man, all he wants is for you to endorse the boundaries of his plot. He's not asking you to do anything illegal. Why are you harassing him? Should he have carried a gun with him, and only then would you have listened to him? Don't make a Naxalite out of him.

The commonly-held connotations of the term 'Naxalite' evoke images of insurgents who flout the law as well as the social authority of local elites: the imagery is often one of social subversion. These meanings trace their roots to the popular mobilisation in northeast Bihar and elsewhere in eastern India over the previous three decades. These movements were often spearheaded by activists of the Communist Party of India (Marxist-Leninist/ Liberation), a party that began its activities in this region during the mid-1980s as the Indian People's Front (Hauser 1993). Following the elections of 1989, the party shed its underground character and assumed its present incarnation, with the explicit goal of militant parliamentarian communism, backed up by popular mobilisation (Jaoul 2011). Its most common form of activism over the last three decades has been to organise the forcible occupation of agricultural land belonging to local landlords by landless agricultural labourers and sharecroppers. To that end, the latter have faced violent attacks from paramilitaries owned by landlords, but have consistently fought back, thereby developing a fearsome reputation among both local elites and bureaucrats.

Thus, the term 'Naxalite' forces a rupture not only in the specific administrative implementation of policies, but of the assumption underpinning the organisation of society. Used by the police, being Naxalite refers to someone who infringes upon the law. Used by landlords, a Naxalite is someone who interrogates their pre-eminence. According to elderly landlords I spoke with, the locality was 'once infested' (pheiley huey the) with Naxalites. Indeed, the figure of the 'Naxalite' is often associated with the destruction of an inegalitarian moral order: in journalist Arun Sinha's words, 'the new man who arose from the flames [of Naxalism] was neither a Harijan nor a Koeri, but a man' (Sinha 1977). ${ }^{14}$ Dharmesh's usage of the term appears to imbibe this usage. When I asked how it was that Dharmesh, a staunch activist of the Hindu Rightist BJP valorised a leftwing concept such as Naxalism, Narendra, with whom we were walking, suggested that his use of the term was a metaphor to convey 'that we too are human beings and need to be treated as such.' For both Dharmesh and Narendra, the invocation of the term was intended to communicate their refusal to remain quiescent to the amin's whimsical attitude. ${ }^{15}$

Narendra's angst is mirrored in his wife's earliest remarks about the dispute between them and their neighbour as being of equality rather than property alone. Recalling Rancière's suggestion that 'egalitarian effects occur only through a forcing, that is, the instituting of a quarrel that challenges the incorporated, perceptible evidence of an inegalitarian logic' (Rancière 2004: 5), it appears that, for the couple, at the core of the dispute lay an attempt to gain recognition as equals of those around them, particularly local elites such as their neighbour, the panchayati elders and the amin. The invocation of the term Naxalite suggests the importance Gunvati and Narendra Yadav attached to being treated as equal (and human). 


\section{Agonistic exchange, equality and dissensus}

neighbours appears to have been a means of extending his mastery over them, perhaps with a view to teach them a lesson for having dared to live in that neighbourhood, or perhaps eventually evict them from it and usurp all of it, or maybe to make their lives more difficult. In their conversations with me, they spoke about the manner in which the 'upper' castes were being marginalised in Bihar, and how this was the reason that Bihar was faring so poorly along every conceivable indicator of 'progress'. They said they had wanted their neighbourhood to be one where 'intelligent peepul (people)' lived, not people with 'backward brains. ${ }^{16}$ My conversations with the couple ceased after these comments, but it appears that the dispute was central for them to assert their customary supremacy over their 'lower'-status neighbours.

I am inclined to believe that Gunvati and Narendra's allegation against Ram Singh is correct and that he was insistent on usurping a part of their property to demonstrate that he could continue to exercise his authority, demonstrate his supremacy and extend his mastery over them with impunity. For the couple, it was as important to challenge this mastery and ensure that it be subjected to legally constituted authority exercised by the formal state. Along with support from the elected upasarpanch, they sough to affirm the 'fact' that they were equals, and could not be pushed around by their more affluent and politically better-connected neighbour. Of course, it is clear that this proved an enormously difficult task, and was impeded by the inability of elected institutions to enforce their own laws and the tardiness and unwillingness of the legal bureaucracy to take the case seriously. But the couple refused to give up without a contest.

Analysing the dispute in terms of a contest enables us to appreciate the manner in which the contending social agents advance their claims and counter-claims. Whereas Ram Singh seeks to undermine the social equality being advanced by Gunvati and Narendra by them having purchased property in their locality, the couple do everything they can to verify it. Where the customary panchayati supports Ram Singh's claims through apparently reasoned considerations, Gunvati and Narendra refuse to submit to its decision calling for a compromise. They realise that it is only through forcing a disagreement, by rejecting the panchayati's authority and by taking the dispute to the domain of the formal state-first, the elected arm and then the legal-bureaucratic one-, that they could do this. For them, the contest was crucial to affirm their sense of social equality vis-à-vis their better-off tormentors.

What do these perspectives on social equality tell us about the politics of people such as Narendra and Gunvati Yadav. One way to think about politics in such circumstances is to think, along with Jacques Rancière, about the idea that 'Politics exists because those who have no right to be counted as speaking beings make themselves of some account' (Rancière 1999: 27). Elsewhere, he contends that '[i]n order to enter into political exchange, it becomes necessary to invent the scene upon which spoken words may be audible, in which objects may be visible, and individuals themselves may be recognised' (Rancière 2000: 116). Furthermore, self-assertion is not only about appealing to shared meanings, or about advancing better arguments but about rupturing those and forcing outwards the boundaries of what are considered acceptable demands to make. As Norval cogently summarises, the assertion of voices involves staging of demands that lie outside 
the 'extant terrain of representation' (Norval 2009: 310). The staging of demands thought to be outside the realm of the possible and the sensible-the affirmation of social equality -constitutes the political imaginary of people such as Gunvati and Narendra Yadav.

Rancière introduces the analytical category of 'dissensus' to refer to the manner in which fundamental assumptions about the prevailing social order are challenged, and the very principles of exclusivist authority are contested. The category of dissensus compels us to rethink the ways in which subjects seek to inflect their perceived world with their critical interpretations (Rancière 2001: 12). Indeed, from the accounts presented thus far, it appears that the Yadav couple and their friends persistently and publicly challenged their neighbours' assumption of social supremacy. Far from 'reasoning', it is a passionate expression of their claims that allows them to stand up to their tormentors and force the dispute further. The couple do not shy away from the public. Indeed, they take their issue to that domain and seek solidarity, a solidarity that is not provided by shared caste, ethnicity or religion, but by incipient socialities based on the imperatives of forging electoral constituencies, coupled with shared experiences of discrimination, humiliation and exploitation. Their refusal to accept Ram Singh's claims, the panchayati's decisions or the amin's tardiness is not merely a story of individual agency and fortitude, facilitated by good Samaritans. It is also not merely a case of Gunvati and Narendra being of the 'right' caste: as I have shown, they appear to have been the 'underclass' among the Yadavs, with the wealthy and propertied Yadavs having consistently backed Ram Singh, of a rival community. Undoubtedly, they are likely to have faced many more hardships had they been Dusadh, Musahar or Kunjra, with fewer social resources, ${ }^{17}$ but their being faced with indomitable structural constraints can hardly be denied.

The starting point for each of these actions was provided by the assumption of equality among the Yadav couple vis-à-vis their wealthier neighbours, and the assertion of their claims based on this assumption. The agonistic exchanges that we witness throughout this paper stem from this postulation of equality as a key feature of the political imaginary of people such as Gunvati and Narendra Yadav. The political mobilisations dotting Bihar's landscape over the last eight decades or so, culminating in Lalu Yadav's ascendance to power in 1990 have reclaimed this premise of equality in the public domain. There is no doubt that widespread (and widening) material inequalities exist, and prevent these premises to be substantiated. But the customary assumptions of hierarchy, authority and supremacy are being constantly interrogated and dismantled across the State, and elsewhere in the country.

\section{Towards conclusions}

51 The amin eventually completed the measurement and awarded the disputed plot of land to Narendra in May 2010, nearly three years after being first approached. To his credit, he did not take a single rupee as bribe-at least that was what Narendra reported to me. Whether or not the 'Naxalite' comment had motivated him or whether he saw himself as making Narendra's life a little easier, we cannot tell. Gunvati and Narendra are undoubtedly happy with this judgment. However, as she tells me, this is only the beginning, as the hostilities they face are even sharper and recognition of them as social equals recognised by those who consider themselves their social superiors remains unforthcoming. They remain particularly sensitive to their 'community identity' being stigmatised and are ever more assertive about defending their 'class-community' position 
from verbal slander by their neighbours. Far from seeing themselves entirely and exclusively as individual citizens, they are proud members of their community with which they see no contradiction as members of the political community. The equality they seek to assert is a social, rather than individual, equality. Any search for Liberal closures in this narrative has proven elusive.

Nonetheless, as agonists unwilling to acquiesce in their domination by their wealthy and well-connected neighbours, Gunvati and Narendra Yadav have contributed to the substantialisation of democracy in rural Bihar. They have sought to assert their presence as social equals, by contesting an elitist consensus and seeking to be incorporated into the 'grid' of the formal state as well as subjecting their tormentors to it. The discussion of their assertions has revealed the role of extra-communitarian socialities (as for instance, cross-caste friendships) as well as the importance placed on negotiations with supra-local institutions and individuals. It is not without irony that in a context where the intersubjective salience of tradition and community are deemed to be valorised, the rural poor find the local state (lethargic and foreboding as it may be) more accessible than socalled deliberative institutions.

The contests are obviously fraught with tensions, and I find the framework of 'agonism' vitally useful to make sense of these tensions fruitfully. On the one hand, the dispute between the neighbours reflects the failure of deliberative, cooperative and cooptive strategies. On the other hand, antagonism is eschewed (as in the sense of relief when a caste conflict is averted) or invoked only momentarily (when Narendra and his friend threaten the amin but do not actively peruse that route). While Gunvati and Narendra reject the authority of the panchayati, they find their ability to access the formal state fractured and fragmented. Even as they seek to be counted by the state and society, it is unclear as to whether they want to do so in the image of liberal citizens of 'modernist' conception. An 'agonistic' framework serves us well in order to understand the dilemmas of these emerging socialities and the ongoing struggles of the world's impoverished to concretise and substantiate their political imaginaries.

\section{BIBLIOGRAPHY}

Beals, Alan and Bernard Siegel (1966) Divisiveness and Social Conflict, Stanford, CA: Stanford University Press.

Caplan, Pat (1995) Understanding Disputes: The Politics of Argument, Michigan: Berg.

Cavell, Stanley (1989) Conditions Handsome and Unhandsome: The Constitution of Emersonian Perfectionism, Chicago: University of Chicago Press.

Clifford, James (1986) 'Introduction: Partial Truths', in James Clifford \& George Marcus (eds.) Writing Culture: The Poetics and Politics of Ethnography, California: University of California Press, pp. $1-26$. 
Cohen, Joshua (1997) ‘Deliberation and Democratic Legitimacy’, in James Bohman \& William Rehg. (eds.) Deliberative Democracy: Essays in Reason and Politics, Cambridge, MA and London: The MIT Press, pp. 67-91.

Cohn, Bernard (1965) 'Anthropological Notes on Dispute and Law in India', American Anthropologist, 67(6), pp. 82-122.

Corbridge, Stuart \& Harriss, John (2000) Reinventing India: Liberalization, Hindu Nationalism and Popular Democracy, The Hague: Wiley.

Dumont, Louis (1970) Homo Hierarchicus: The Caste System and its Implications, Chicago: University of Chicago Press.

Frankel, Francine (1989) 'Caste, Land and Dominance in Bihar: Breakdown of the Brahmanical Social Order', in Francine Frankel \& MSA Rao (eds.) Dominance and State Power in Modern India: Decline of a Social Order, Vol. 1. Oxford: Oxford University Press, pp. 46-132.

Fung, Archon (2005) 'Deliberation Before the Revolution: Towards an Ethics of Deliberative Democracy in an Unjust World', Political Theory, 33(3), pp. 397-419.

Galanter, Marc (1963) 'Law and Caste in Modern India', Asian Survey, 3(11), pp. 544-59.

Goodwin, Jeff, Jasper, James \& Francesca Polletta (2001) Passionate Politics: Emotions and Social Movements, Chicago: University of Chicago Press.

Habermas, Jürgen (1996) ‘Three Normative Models of Democracy’ in Seyla Benhabib (ed.) Democracy and Difference: Contesting the Boundaries of the Political, Princeton NJ: Princeton University Press, pp. 21-30.

Hauser, Walter (1993) 'Violence, Agrarian Radicalism and Electoral Politics: Reflections on the Indian People’s Front, Journal of Peasant Studies, 33(1), pp. 89-123.

Herzfield, Michael (1995) 'It Takes One to Know One: Collective Resentment and Mutual Recognition among Greeks in Local and Global Contexts', in Richard Farndon (ed.) Counterworks: Managing the Diversity of Knowledge, London : Routledge, pp. 118-36.

Jannuzi, F. Tomasson (1974) Agrarian Crisis in India: The Case of Bihar, Austin: University of Texas Press.

Jansen, Steff (2013) ‘Hope for/against the state: gridding in a besieged Sarajevo suburb’ Ethnos 78 [pre-published on-line 16 Jan 2013].

Jaoul, Nicolas (2009) 'Naxalism in Bihar: From Bullet to Ballot', in Laurent Gayer and Christophe Jaffrelot (eds.) Armed Militias of South Asia: Fundamentalists, Maoists and Separatists, New York: Columbia University Press, pp. 21-43.

Jaoul, Nicolas (2011) 'Maju Devi’s Martyrdom: Marxist-Leninist Politics and the Rural Poor in Bihar', Contributions to the Indian Sociology 45 (3), pp. 343-71.

Malinowski, Bronislaw (1967) A Diary in the Strict sense of the Term, London: Routledge \& Kegan Paul.

Marcus, George \& Fischer, Michael (1999) Anthropology as Cultural Critique: An Experimental Moment in the Human Sciences, Chicago: University of Chicago Press.

Mouffe, Chantal (1992) The Dimensions of Radical Democracy: Pluralism, Citizenship, Community. London, New York: Verso

Mouffe, Chantal (1996) 'Democracy, Power and the 'Political”, in Seyla Benhabib (ed.) Democracy and Difference, Princeton: Princeton University Press, pp. 245-55. 
Mouffe, Chantal (1999) Deliberative Democracy or Agonistic Pluralism, Social Research, 66(3), pp. 745-58.

Mouffe, Chantal (2007) On the Political, London, New York: Verso.

Norval, Aletta (2007) Aversive Democracy: Inheritance and Originality in the Democratic Tradition, Cambridge: Cambridge University Press.

Pocock, David (1973) Mind, Body and Wealth: A Study of Belief and Practice in an Indian Village, The Hague: John Wiley and Sons.

Potter, Jonathan (2009) 'Discourse analysis as a way of analysing naturally occurring talk', in David Silverman (ed.) Qualitative Research, New Delhi, London: Thousand Oaks, pp. 200-21.

Rabinow, Paul (1977) Reflections on Fieldwork in Morocco, Berkeley: University of California Press. Rancière, Jacques (1992) ‘Politics, Identification and Subjectivization', The Identity in Question, 61, pp. 58-64.

Rancière, Jacques (1999) Disagreement: Politics and Philosophy, Minneapolis: University of Minnesota Press.

Rancière, Jacques (2001) 'Ten theses on politics', in Davide Panagia (trans.), Theory \& Event, 5(3) (http://muse.jhu.edu/journals/theory_and_event/v005/5.3ranciere.html).

Rancière, Jacques (2004) 'Introducing Disagreement', Angelaki: Journal of Theoretical Economics, 9(3), pp. 3-9.

Rawls, John (1997) 'The Idea of Public Reason Revisited', The University of Chicago Law Review, 64(3), pp. 765-807.

Robin, Cyril (2009) 'Bihar: The New Stronghold of OBC Politics', in Christophe Jaffrelot \& Sanjay Kumar (eds) Rise of the Plebians? The Changing Face of Indian Legislative Assemblies, New Delhi: Routledge.

Singh, Bhrigupati (2011) 'Agonistic Intimacy and Moral Aspiration in Popular Hinduism: A Study in the Political Theology of the Neighbour', American Ethnologist, 38(3), pp. 430-50.

Smith, Anna Marie (1996) Laclau and Mouffe: The Radical Democratic Imaginary, London: Routledge.

Thorner, Daniel \& Thorner, Alice (1962) Land and Labour in India, Delhi: Asia Publishing House.

White, Luisie (2001) 'True Stories: Narrative, Event, History and Blood in the Lake Victoria Basin', in Luisie White, Stephan Miescher, David Cohen (eds.) African Words, African Voices: Critical Practices in Oral History, Bloomington, Indiana: Indiana University Press, pp. 281-304.

\section{NOTES}

1. Hanging out, Gunvati and Narendra Yadav's household, January 9, 2010.

2. Sargana Gram Panchayat comprised twelve wards, one oh which was Sargana Ward 1

3. As of June 16, 2013, Nitish Kumar withdrew from the alliance due to the BJP's rightward shift under party strongman Narendra Modi, Chief Minister of the State of Gujarat, whose administration was notorious for widespread violence against Muslims in 2002.

4. The State has allocated ' 18,000 crores for investing on improving roads: the number of constructed kilometers in the State increased from 384.6 in 2004-5 to 3474 in 2009-10 (Mishra, 2011).

5. Interview, Gunvati Yadav, April 1, 2010. All cited matter till the next footnote from this source. 
6. A legal document indicating the precise boundaries that a plot had, in relation to neighbouring plots.

7. Interview, Gunvati Yadav, January 25, 2010. All cited material till next footnote from this source.

8. Interview, Gunvati Yadav, January 23, 2010

9. Hanging out, Gunvati Yadav's residence, January 25, 2010

10. Interview, Dharmesh Srivastav, March 19, 2010

11. Interview, Gunvati Yadav, January 25,2010

12. Classified as Extremely Backward Class in Bihar. This locality had been characterized by a history of Kevat-Yadav alliance against the Rajput landlords, but that history did not seem to influence the amin in any direction.

13. Hanging out, Sargana BDO Office Lawns, April 16, 2010. The rest of the account is based on the same source.

14. This imagery is admittedly not shared by many younger Dalits in my study localities, including the children of long-term activists: they point to a "lack of respect" towards Dalits in the party and to cases when "upper" caste leaders have avoided commensal relations with them.

15. Amaresh, on the other hand, remained impassive and unimpressed throughout the conversation. Once home, he told Narendra off for losing his cool, complaining to Gunvati that his outburst threatened to ruin everything. He taunted Narendra for his Naxalite comment, suggesting- somewhat unfairly and inaccurately- that Naxalite activism was not for the poor!

16. Interview, Ram Singh, January 17, 2010. At the gates of his residence.

17. It remains a moot question as to whether they would have backed or supported individuals of these communities in similar circumstances, where the perpetrator might have been Yadav.

\section{ABSTRACTS}

The literature on the politics of the 'poor' has pointed to the manner in which the disputes they are embroiled in are about access to and control over resources, or defending what little they have from encroachments and infringements by the rich and the powerful. Other strands in the literature have drawn attention to their incorporation into 'identity' politics, mediated through categories of caste, religion and community. While the analytic salience of these approaches may be justifiably questioned, I contend that they are also motivated by a desire to assert their social equality and accomplish their political imaginaries. To attain their objectives, the 'poor' supposedly draw on their cultural resources-such as the language of fictive kinship, the moral claims on socially 'superior' individuals or pleading with powerful patrons-to advance their claims or defend their interests. Specific variants of this argument stress that their interaction with the state tends to be fragmentary and, as a result, they seek evasion from the law- either through autonomy or exemption. While it is not entirely untrue that cultural resources are sometimes deployed, or that access to the state is often fragmented, I suggest that these do not deter the 'poor' from seeking greater, not lesser, access to the state and its de jure versions.

In this paper, I intend to discuss the manner in which the rural poor in one of India's most impoverished regions engage with and in politics. I will do this by analyzing the way in which a landless Yadav couple tries to forestall the perpetuation by their wealthy Rajput neighbour of, and eventually contribute to the rupture of, elite-based consensus in their neighbourhood. I find 
the framework of 'agonism' vitally useful to make sense of these tensions fruitfully. On the one hand, the dispute between the neighbours reflects the failure of deliberative, cooperative and cooptive strategies. On the other hand, antagonism is eschewed or invoked only momentarily. While the couple rejects the authority of the panchayati, they find their ability to access the formal state fractured and fragmented. Even as they seek to be counted by the state and society, it is unclear as to whether they want to do so in the image of liberal citizens of 'modernist' conception. An 'agonistic' framework serves us well in order to understand the dilemmas of these emerging socialities and the ongoing struggles of the world's impoverished to concretize and substantiate their political imaginaries.

INDEX

Keywords: Bihar, caste, agonism, disputes

\section{AUTHOR}

INDRAJIT ROY

Junior Research Fellow, University of Oxford 